\title{
FIRST OCCURENCE OF CAULERPA MACRODISCA (CAULERPACEAE, CHLOROPHYTA) IN MALAYSIA BASED ON THE MOLECULAR AND MORPHOLOGICAL EVIDENCE
}

\author{
Wahidatul Husna Zuldin ${ }^{1 a^{*}}$, Rossita Shapawi ${ }^{2 a}$, Sitti Raehanah Muhamad Shaleh ${ }^{3 a}$, Nazia \\ Abdul Kadar ${ }^{4 a}$ and Tamrin M. Lal ${ }^{5 a}$
}

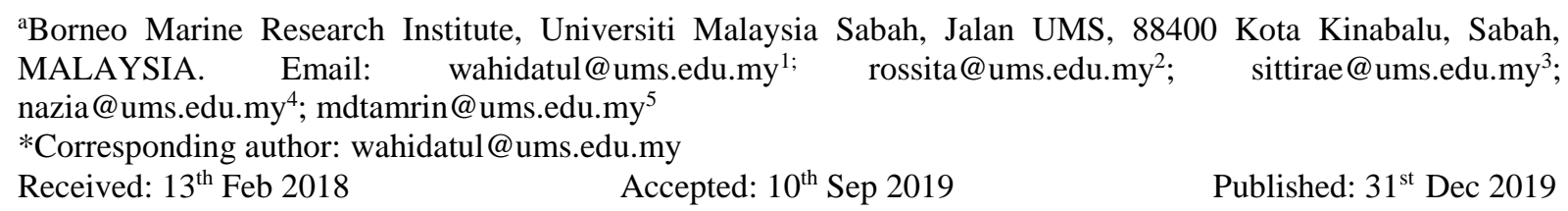
DOI: https://doi.org/10.22452/mjs.vol38no3.7

\begin{abstract}
The siphonous green macroalgae Caulerpa macrodisca (Decaisne) Weber-van Bosse has been reported to be widely distributed around South-west Asia (Sri Lanka), South China Sea, South-east Asia (Indonesia, the Philippines, Singapore and Vietnam) and Pacific Islands (Samoan Archipelago). There was no formal report on the existence of $C$. macrodisca in Malaysia. This study reports the first occurence of the green algae, $C$. macrodisca in the coastal area of Menumbok, Sabah, Malaysia. The $C$. macrodisca was first discovered in March 2016, and grew around the sea cage of a local farmer in Sikalong Village, Menumbok. In May and July 2016, we searched around the coastal area near the sea cage and the existence of $C$. macrodisca was discovered at 1.4 to $2.7 \mathrm{~m}$ depth. Further scuba search was done in August 2016 and confirmed its occurrence nearby the area at similar depth. Most of the collected green macroalgae were large and reproductive with a few were small and young but precociously reproductive. The samples were collected in May, July and August 2016 for further analysis. The collected specimen was confirmed as $C$. macrodisca through morphology and genetic analyses using tufA gene as DNA biomarker. In conclusion, the first occurrence of C. macrodisca in Malaysia added a new record for the South China Sea region marine algae checklist.
\end{abstract}

Keywords: Caulerpa macrodisca, first occurence, new record, Malaysia, Sabah, tufA gene.

\section{INTRODUCTION}

The genus Caulerpa, described by Lamoroux in 1809 belongs to the group Bryopsidophyceae comprised of about 75 species and mostly found in temperate and tropical waters (Lewmanomont, 2008). In the Malaysian waters, there are approximately thirteen species and seven varieties of Caulerpa being identified and recorded. Eight species that commonly found are $C$. lentillifera, $C$. peltata, $C$. racemosa, C. scalpelliforms, $C$. serrulata, $C$. sertulariodes, $C$. taxifolia and $C$. verticillata (Phang, 2007). Nevertheless, none have properly reported the existence of $C$. macrodisca in Malaysia. The $C$. macrodisca was first introduced by Decaisne in 1842 localized around Anambas Island, Indonesia. This species is found to be distributed around Vietnam, Australia, New Zealand, Republic of Palau, Sri Lanka, South China Sea, Indonesia, the Philippines, Singapore and Samoan Archipelago (Belton et al., 2015; Price, 2011).

Caulerpa macrodisca was previously named as $C$. racemosa (Forsskal) J. Agardh var. macrodisca (Decaisne) Weber-van Bosse and C. peltata J.V. Lamoroux var. macrodisca (Decaisne) Weber-van Bosse (Belton et al., 2014). However, due to the phenotypic plasticity 
as described by Belton et al. (2014), the species remains as solely $C$. macrodisca. This species is locally known as "eabaeaba" in Iloilo, the Philippines that are collected seasonally from the wild by divers, sold in the local markets and consumed as fresh salads. Caulerpa macrodisca is a type of green macroalgae that is believed to be used as a kind of natural food and fibre without toxic and harmful effect to human (Movahhedin et al., 2012). Nevertheless, there is limited information available for the nutritional properties of C. macrodisca.

The green seaweed, C. macrodisca is reported to be locally extinct in Cebu, the Philippines due to the massive reclamation activities that have decimated the algal populations (Belleza and Liao, 2007). In fact, the $C$. macrodisca is recently reported by Phang et al. (2016) to be found only in the coastal area of Singapore, Thailand and Vietnam, not in other area. This recent finding indicates that the information on the distribution of $C$. macrodisca is limited and scarce. The C. macrodisca is recently found to be abundant in the coastal area of Menumbok, Sabah, Malaysia. The first occurrence of $C$. macrodisca at the Malaysian waters provides a new record and information update for the checklist of marine algae in the South China Sea region.

\section{MATERIALS AND METHODS}

\section{Specimens Collections}

Specimens of green macroalgae, Caulerpa X were collected from the sampling site, coastal area of Sikalong Village, Menumbok twice in May and July 2016. Further scuba searches were performed in August 2016 and the samples were also collected (Figure 1). The specimens were brought to the Borneo Marine Research Institute for further analysis during every visit to the sampling site. The environmental parameters (salinity, temperature, $\mathrm{pH}$ and dissolved oxygen (DO) level) at the sampling site were recorded during the specimen collection.

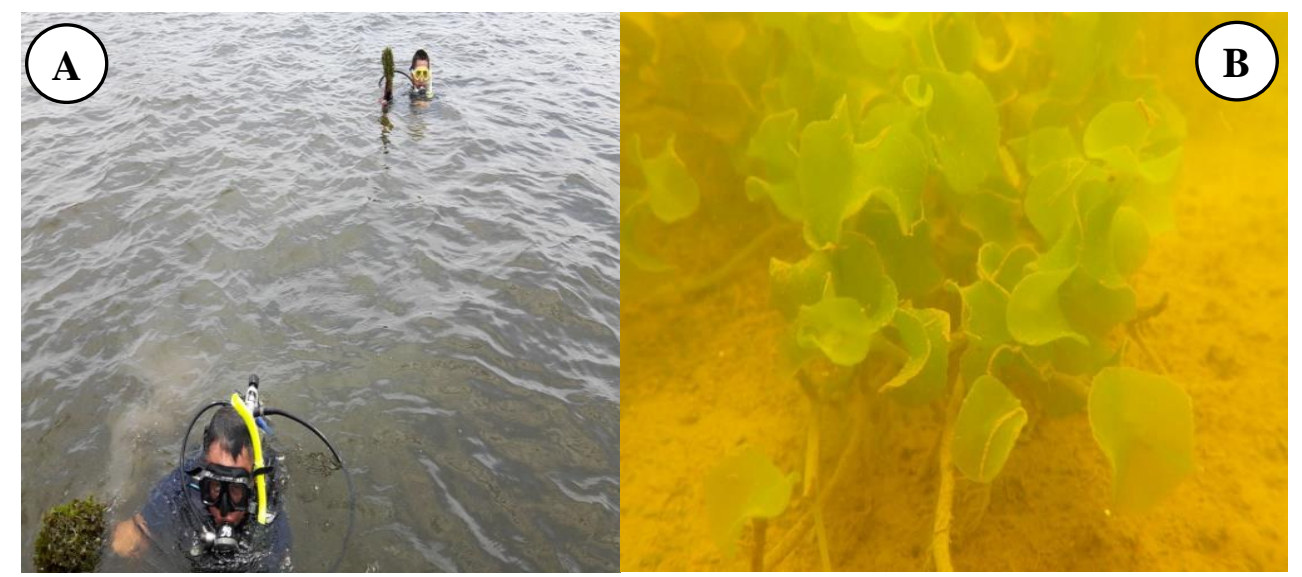

Figure 1. (A) Scuba search for C. macrodisca at the sampling site and (B) The photograph of C. macrodisca captured at the sea bottom surface in Menumbok.

\section{DNA Isolation and PCR Amplification}

Genomic DNA was extracted from $100 \mathrm{mg}$ of fresh Caulerpa $\mathrm{X}$ thallus using CTAB (Cetrimethyl Ammonium Bromide) extraction method as described by Cota-
Sánchez et al. (2006). A partial section ( $900 \mathrm{bp}$ ) of the tufA gene was amplified through Polymerase Chain Reaction (PCR) using forward and reverse primer sequences designed by Fama et al. (2002) and Stam et al. (2006): tufGF4 5'- 
TGAAACAGAAMAWCGTCATTATGC-
3 , CCATAGGAATTGGACTATCA-3'. Both fragments were amplified in $25 \mu \mathrm{L}$ reaction volumes containing $0.75 \mu \mathrm{L}$ of each primer, $8.0 \mu \mathrm{L}$ of PCR buffer, $1.0 \mu \mathrm{l}$ of template DNA $(50 \mathrm{ng}), 0.5 \mu \mathrm{L}$ of Taq DNA polymerase (1.25 units), $3.0 \mu \mathrm{L}$ of dNTP (mix), $1.5 \mu \mathrm{L}$ of $\mathrm{MgCl}_{2}$ and $9.5 \mu \mathrm{L}$ nuclease free water, $\mathrm{dH}_{2} \mathrm{O}$. Thermocycling (Applied Biosystems $^{\mathrm{TM}}$, Applied Biosystems Inc, USA) comprised initial step of $2 \mathrm{~min}$ at $94^{\circ} \mathrm{C}$ and 25 cycles of $10 \mathrm{~s}$ at $98^{\circ} \mathrm{C}, 30 \mathrm{~s}$ at $52^{\circ} \mathrm{C}$, and $50 \mathrm{~s}$ at $68^{\circ} \mathrm{C}$, with final extension at $72^{\circ} \mathrm{C}$ for $5 \mathrm{~min}$. The PCR products were checked on $1.0 \%$ agarose gel after amplification. Successful PCR product was then further purified using the Mega-spin (TM) PCR Product Purification kit (INTRON, Biotechnology, Seongnam-Si, Korea). The purified PCR product was sent to First BASE Laboratories Sdn. Bhd. (Seri Kembangan, Malaysia) for sequencing.

\section{BLAST Search, Sequence Alignment and Phylogenetic Analysis}

The sequencing data of Caulerpa $\mathrm{X}$ was viewed and edited using Chromas version 2.6. All positions containing gaps and missing data were eliminated with a total of 921 positions in the final dataset. The sequence was then analyzed using Basic Local Alignment Search Tools (BLAST) for sequence homology search in GenBank. The sequence of Caulerpa $\mathrm{X}$ and other Caulerpa sequences retrieved from GenBank as mentioned in Table 1 were then aligned using Clustal $X$ in Mega 7.0 software (Larkin et al., 2007). Sequence alignments were analyzed and evolutionary tree was constructed using the Maximum Likelihood (ML) based on the Tamura-Nei model with 1000 bootstrap replicates. Nucleotide sequences from genus Eucheuma (KU362117) and Sargassum (KU362150) were included as outgroups in the analysis. The tree was drawn to scale, with branch lengths measured in the number of substitutions per site (Larkin et al., 2007).

Table 1. The information of other Caulerpa gene sequences using tufA gene as DNA marker retrieved from the GenBank.

\begin{tabular}{lcl}
\hline \multicolumn{1}{c}{ Species } & $\begin{array}{c}\text { Accession } \\
\text { Number }\end{array}$ & \multicolumn{1}{c}{ Reference } \\
\hline $\begin{array}{l}\text { Caulerpa macrodisca } \\
\text { Caulerpa peltata var. } \\
\text { peltata }\end{array}$ & KF256095 & Belton et al. (2014) \\
\hline Caulerpa macrodisca & JN817666 & Belton et al. (2014) \\
\hline Caulerpa racemosa & JN645154 & Sauvage et al. (2013) \\
\hline Caulerpa racemosa & JN645149 & Sauvage et al. (2013) \\
\hline Caulerpa racemosa & JN817664 & Belton et al. (2014) \\
\hline Caulerpa parvifolia & FM956029 & Darisma and Prud'homme van Reine (2008) \\
\hline Caulerpa serrulata & KJ957117 & Sauvage and Sherwood (2014) \\
\hline Caulerpa antoensis & KJ957107 & Sauvage and Sherwood (2014) \\
\hline Caulerpa chemnitzia & KJ957102 & Sauvage and Sherwood (2014) \\
\hline Caulerpa manorensis & FN667649 & Darisma and Prud'homme van Reine (2008) \\
\hline
\end{tabular}

\section{Morphological Analysis}

Morphological observations were performed after every specimen collections on five characteristic: rhizoid form, stolon width, upright fronds height and disc diameter and arrangement (Figure 2). The specimens were morphologically identified 
based on the comparisons with type specimens, original descriptions and various taxonomic references (Belton et al., 2014; Lewmanomont, 2008). The taxonomy was also personally confirmed with Dr. John M. Huisman, a taxonomist from Murdoch University.

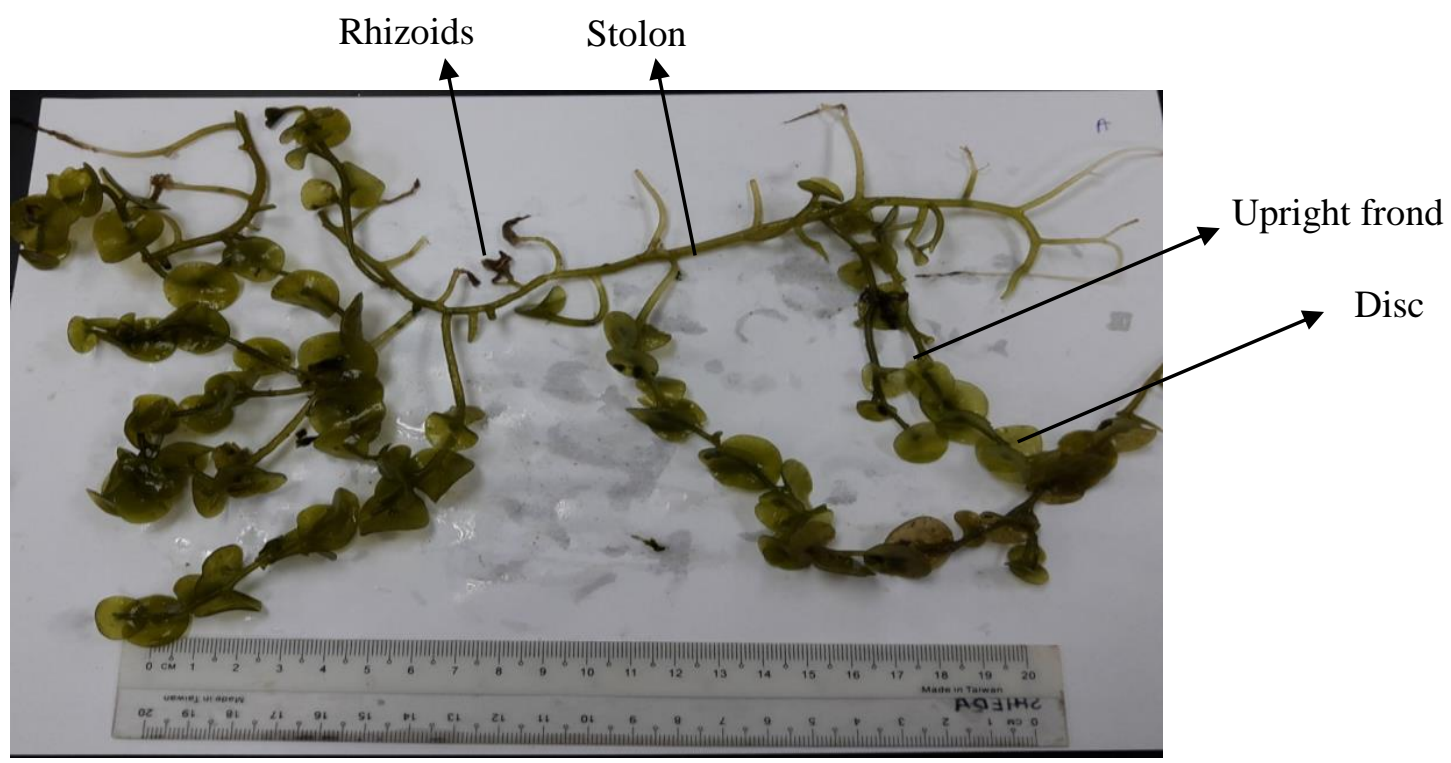

Figure 2. The $C$. macrodisca plant collected from the coastal area of Menumbok and measured morphologically.

\section{Herbarium Preparation for Further Morphological Analysis}

The specimens were also pressed into herbarium for further morphology comparison. Standard method of herbarium specimen preparation was used that involved field visit, specimen collection, pressing/drying, mounting, preservation, labelling and storage (Bridson and Forman, 1998). The specimens were pressed onto herbarium and compared with other Caulerpa species herbarium deposits from University of California Berkeley, Tokyo University of Fisheries and New York Botanical Garden. The herbarium of Caulerpa $\mathrm{X}$ was deposited at the Borneo Marine Research Institute.

\section{RESULTS}

\section{Distribution and Ecology}

The colonies of Caulerpa $\mathrm{X}$ were found in a single transect covering four coordinates (A: N05 ${ }^{\circ} 18.933^{\prime}$, E115²2.399', $\quad$ B: $\quad$ N05 $^{\circ} 18.109^{\prime}$, E115 22.417 ', $\quad$ C: $\quad \mathrm{N}^{\circ} 5^{\circ} 18.167^{\prime}$, E115 $22.397^{\prime}$ and D: N05 ${ }^{\circ} 18.227^{\prime}$, $\left.\mathrm{E} 115^{\circ} 22.422^{\prime}\right)$ around the coastal area near Sikalong Village and Labuan Ferry Terminal, Menumbok (Figure 3). The depth in each coordinate $\mathrm{A}, \mathrm{B}, \mathrm{C}$ and $\mathrm{D}$ were 2.7 $\mathrm{m}, 1.4 \mathrm{~m}, 2.3 \mathrm{~m}$ and $2.4 \mathrm{~m}$, respectively. The sediments were mostly medium silted sand around the areas. The environmental characteristics were recorded during every sampling and ranged averagely as follows: temperatures from 29.83 to $31.89^{\circ} \mathrm{C}$, salinities from 28.08 to $30.15 \mathrm{ppt}$, dissolved oxygen level from 3.85 to $4.81 \mathrm{mg} / \mathrm{L}$ and $\mathrm{pH}$ from 6.14 to 7.23 . 


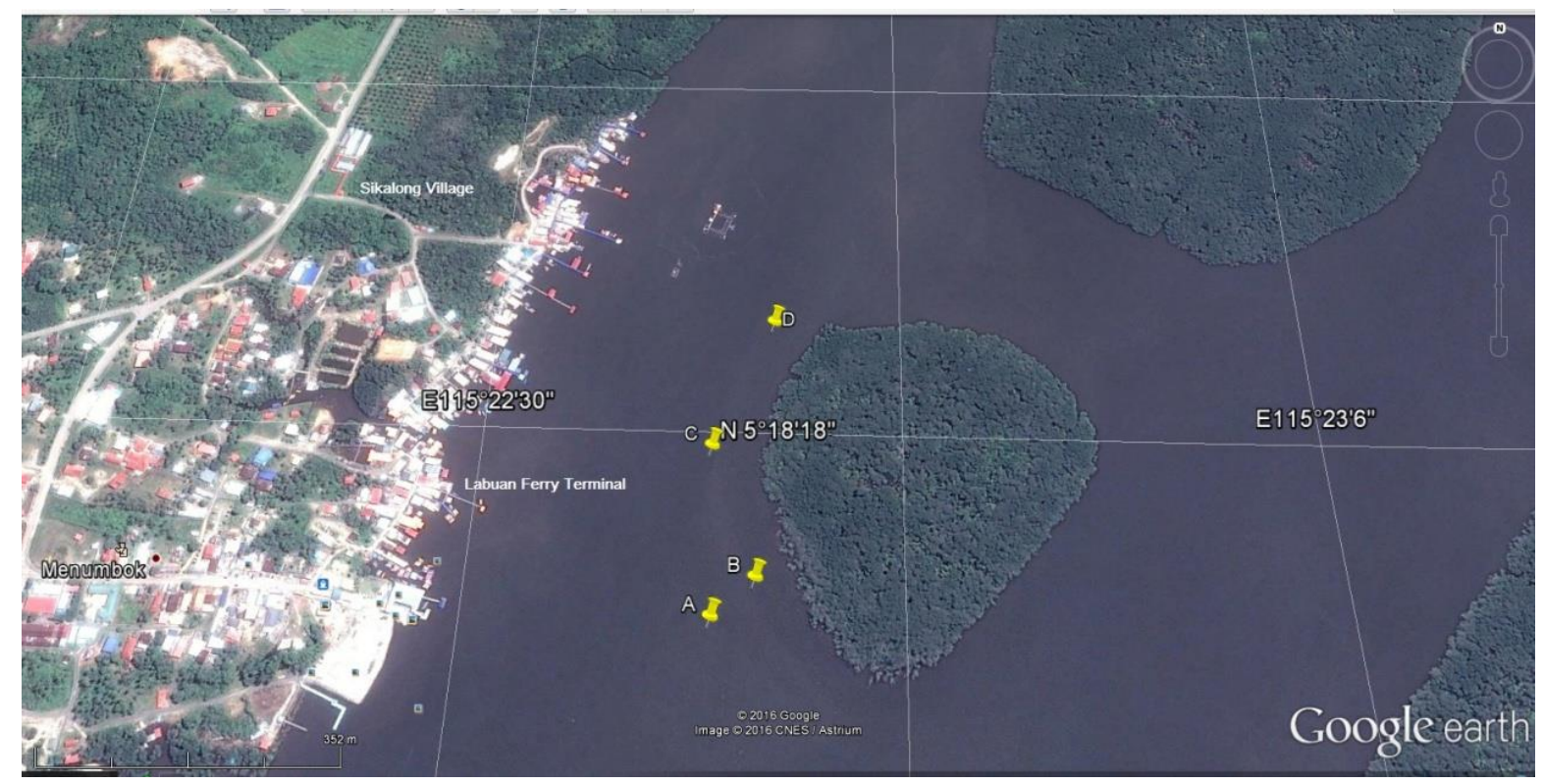

Figure 3. The distribution of C. macrodisca around the coastal area of Sikalong village, Menumbok.

\section{Molecular and Phylogenetic Data}

Amplified PCR product produced clear single bands and direct sequencing resulted in good sequences (Figure 4). Based on the phylogenetic analyses, the collected specimen was identified as Caulerpa $\mathrm{X}$ and grouped under the same clade with genus Caulerpa (Figure 5). The homology search of tufA sequence using
BLAST analysis revealed that Caulerpa X had a 99\% similarity with Caulerpa macrodisca (KF256095) whereby the genetic distance was shorter $(0.010 \%)$. On top of that, Caulerpa X, clustered with Caulerpa macrodisca (KF256095) was strongly supported by high bootstrap value of $98 \%$. The highest intraspecies genetic distance was observed between Caulerpa $\mathrm{X}$ and Caulerpa manorensis $(0.42 \%)$.

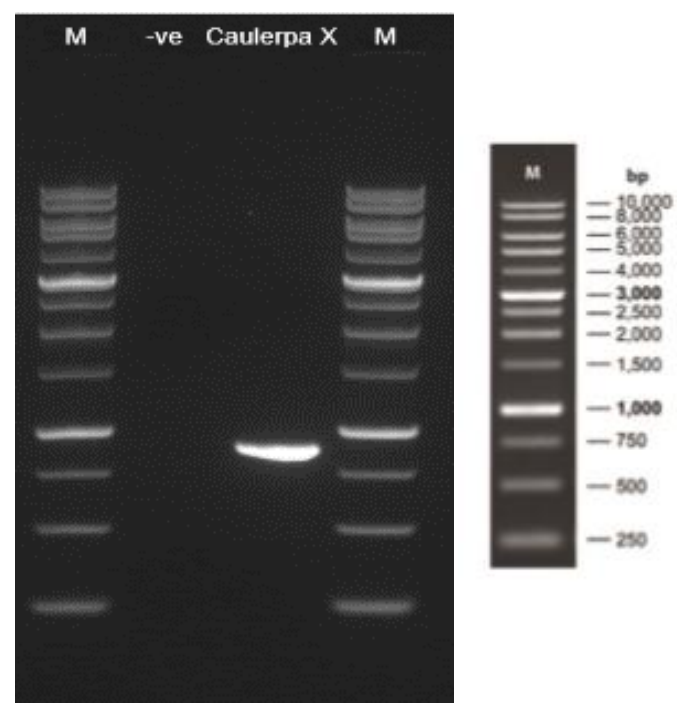

Figure 4. Image of PCR product run on the 1.0\% agarose gel electrophoresis. The "-ve" is a no-template control (water to replace DNA). A total of $1 \mu 1$ of gDNA sample Caulerpa X was used in one $25 \mathrm{ul} \mathrm{PCR}$ reaction. Only $1 \mu \mathrm{l}$ of PCR product was analysed on $1.0 \%$ TAE agarose gel at $100 \mathrm{~V}, 65 \mathrm{~min}$. 


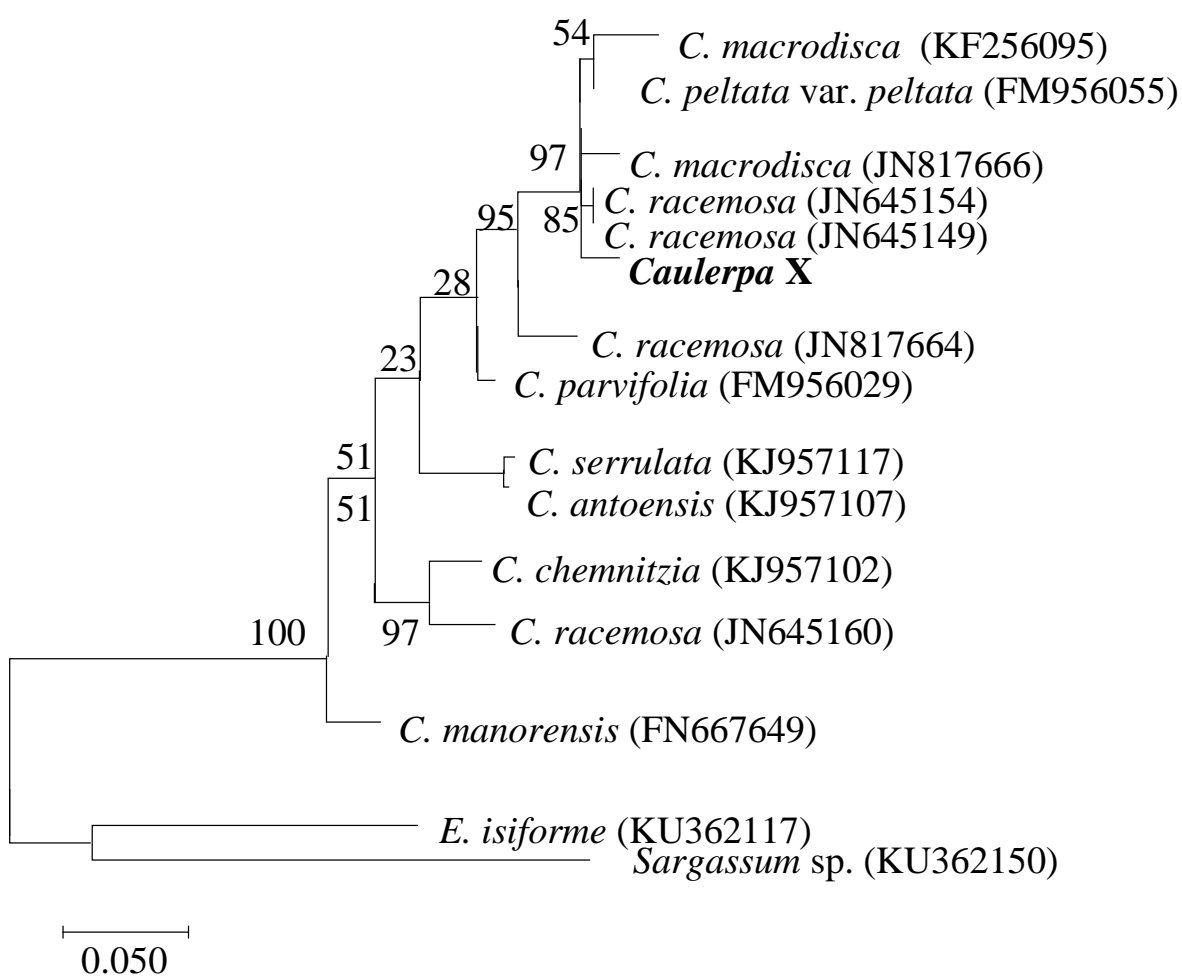

Figure 5. The phylogenetic evolutionary tree of Caulerpa generated using the 1000 bootstrap Maximum Likelihood method based on the Tamura-Nei model involving 12 nucleotide sequences and 2 outgroups species with tufA gene as DNA marker.

\section{Morphological Data}

All the collected specimens named as Caulerpa $\mathrm{X}$ exhibited the usual morphology of $C$. macrodisca. The collected specimens were stoloniferous with terete branching stolons (2.0 to $5.0 \mathrm{~mm}$ in diameter), frequent upright fronds varying from 3.2 to $17.5 \mathrm{~cm}$ high bearing peltate discs which grew out at many angles from the frond and also frequent short rhizoids. The discs were wide and thin with the diameter varied from 2.0 to $27.0 \mathrm{~mm}$ (Table 2). The number of upright fronds were 10 to 18 fronds per $15 \mathrm{~cm}$ of the stolon. These morphologies were mostly similar to the $C$. macrodisca (Decaisne) Weber-van Bosse as described by Belton et al. (2014) and Lewmanomont (2008). The morphology of the specimen was also discovered to be highly similar with the $C$. macrodisca preserved specimen deposited in University of California Berkeley (Figure $6)$. The specimen was also confirmed as $C$. macrodisca by Dr. John M. Huisman, a seaweed taxonomist from Murdoch University. 
Table 2. The morphological data of $C$. macrodisca compared with different Caulerpa species

\begin{tabular}{|c|c|c|c|c|c|}
\hline $\begin{array}{c}\text { Morphology } \\
\text { Characteristics }\end{array}$ & $\begin{array}{c}C . \\
\text { macrodisca } \\
\text { from } \\
\text { Menumbok }\end{array}$ & $\begin{array}{c}C . \\
\text { macrodisca } \\
\text { (Decaisne) } \\
\text { Weber-van } \\
\text { Bosse }\end{array}$ & $\begin{array}{c}\text { C. racemosa } \\
\text { var. } \\
\text { corynephora }\end{array}$ & $\begin{array}{c}\text { C. racemosa } \\
\text { f. } \\
\text { macrophysa }\end{array}$ & $\begin{array}{c}\text { C. peltata } \\
\text { J.V. } \\
\text { Lamouroux }\end{array}$ \\
\hline Stolon diameter & $2.0-5.0 \mathrm{~mm}$ & $1.4-3.3 \mathrm{~mm}$ & $1.4-2.9 \mathrm{~mm}$ & $1.0-2.5 \mathrm{~mm}$ & $1.2-1.9 \mathrm{~mm}$ \\
\hline Fronds Height & $3.2-10.5 \mathrm{~cm}$ & $2.5-7.0 \mathrm{~cm}$ & $6.0-23.0 \mathrm{~cm}$ & $1.0-5.0 \mathrm{~cm}$ & $0.8-5.0 \mathrm{~cm}$ \\
\hline $\begin{array}{l}\text { Shape and } \\
\text { Arrangement of } \\
\text { Ramuli }\end{array}$ & $\begin{array}{l}\text { Ramuli are } \\
\text { disc-shaped } \\
\text { appeared to } \\
\text { be wider } \\
\text { and thinner, } \\
\text { grew out at } \\
\text { many } \\
\text { angles from } \\
\text { the frequent } \\
\text { upright } \\
\text { frond. }\end{array}$ & $\begin{array}{c}\text { Peltate } \\
\text { ramuli } \\
\text { (discs) are } \\
\text { wide and } \\
\text { thin grow out } \\
\text { at many } \\
\text { angles from } \\
\text { rachis } \\
\text { (fronds). }\end{array}$ & $\begin{array}{l}\text { Longer } \\
\text { ramuli } \\
\text { elongate in } \\
\text { form with } \\
\text { swollen tips } \\
\text { and the } \\
\text { shorter } \\
\text { ramuli are } \\
\text { club shaped. }\end{array}$ & $\begin{array}{l}\text { Subspherical } \\
\text { or } \\
\text { mushroom- } \\
\text { like ramuli } \\
\text { grow out } \\
\text { from the } \\
\text { rachis at } \\
\text { many } \\
\text { angles. }\end{array}$ & $\begin{array}{c}\text { Discs are } \\
\text { peltate form, } \\
\text { most are } \\
\text { flat, and the } \\
\text { smaller ones } \\
\text { appear } \\
\text { somewhat } \\
\text { mushroom- } \\
\text { like, } \\
\text { rounded on } \\
\text { top, similar } \\
\text { to the } C \text {. } \\
\text { macrophysa. }\end{array}$ \\
\hline $\begin{array}{l}\text { Ramuli } \\
\text { diameter }\end{array}$ & $\begin{array}{c}2.0-27.0 \\
\mathrm{~mm}\end{array}$ & $4.5-17.5 \mathrm{~mm}$ & $7.0-12.9 \mathrm{~mm}$ & $2.0-5.0 \mathrm{~mm}$ & $2.6-7.0 \mathrm{~mm}$ \\
\hline Rhizoids Type & $\begin{array}{l}\text { Short and } \\
\text { frequent } \\
\text { rhizoids. }\end{array}$ & $\begin{array}{l}\text { Appeared } \\
\text { frequent than } \\
\text { the upright } \\
\text { fronds. }\end{array}$ & $\begin{array}{c}\text { Many } \\
\text { branched } \\
\text { rhizoids } \\
\text { attached at } \\
\text { substratum. }\end{array}$ & $\begin{array}{c}\text { Short } \\
\text { rhizoids } \\
\text { develop on } \\
\text { rock, long } \\
\text { ones on sand } \\
\text { and other } \\
\text { penetrable } \\
\text { materials. }\end{array}$ & $\begin{array}{c}\text { Short } \\
\text { rhizoids } \\
\text { with few } \\
\text { branches. }\end{array}$ \\
\hline
\end{tabular}


When compared to other Caulerpa species, the disc-shaped ramuli of Caulerpa $\mathrm{X}$ was wider and thinner that grew out from different angles of the frequent fronds; whereas the ramuli of other Caulerpa sp. such as $C$. racemosa var. corynephora, $C$. racemosa f. macrophysa and C. peltata are much smaller and different in shapes. For instance, the ramuli of $C$. racemosa var. corynephora appeared to be in two different forms: longer ramuli with swollen tips and shorter ramuli with club-shaped tips. Major differences on the ramuli shapes were also noticed between $C$. racemosa f. macrophysa, C. peltata and Caulerpa X. The differences were also exhibited on the diameter of the ramuli between Caulerpa $\mathrm{X}$ and other C. macrodisca which is Caulerpa $\mathrm{X}$ has wider diameter of the stolons and discs compared to what described in the literature. The minimum ramuli diameter of Caulerpa $\mathrm{X}$ was $2.0 \mathrm{~mm}$ and the maximum diameter was $27.0 \mathrm{~mm}$ which was comparable with the ramuli diameter of $C$. macrodisca that ranged from $4.5 \mathrm{~mm}$ to $17.5 \mathrm{~mm}$.

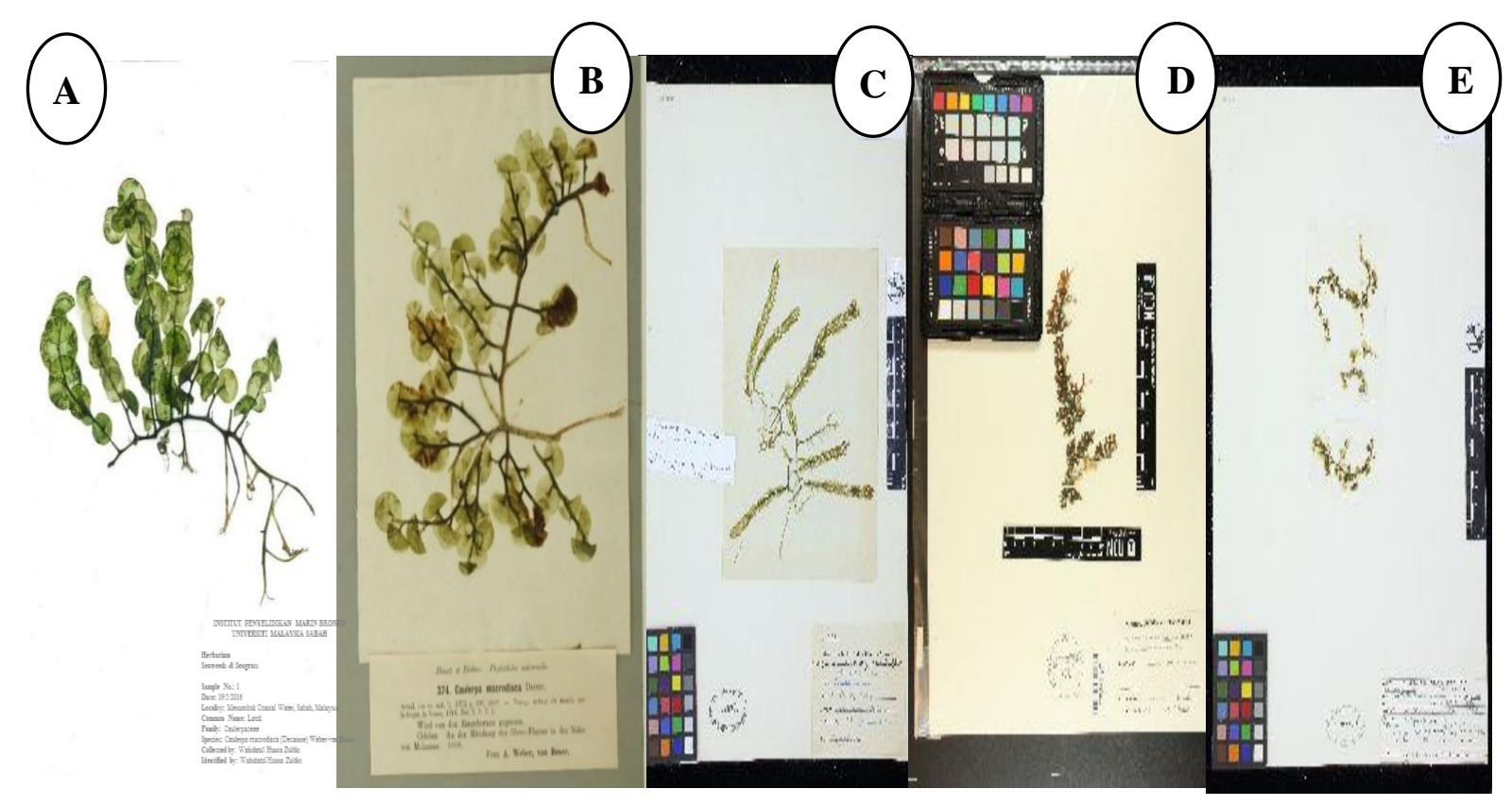

Figure 6. Herbaria collections of Caulerpa species. (A) The collected C. macrodisca specimen from Menumbok. (B) C. macrodisca deposited at University of California Berkeley, (C) Caulerpa racemosa var. corynephora deposited at The New York Botanical Garden, (D)

Caulerpa racemosa f. macrophysa deposited at Tokyo University of Fisheries and (E)

Caulerpa peltata J.V. Lamouroux deposited at The New York Botanical Garden.

\section{DISCUSSIONS}

\section{Distribution and Ecology}

The C. macrodisca was found abundantly occured in a single transect near the coastal area of Menumbok, Sabah, Malaysia. Based on the literature, $C$. macrodisca is found to be distributed around the coastal waters of Singapore, the
Philippines, Indonesia, Vietnam, Australia, New Caledonia, Oman, Thailand, Florida, New Zealand, Republic of Palau, Sri Lanka and Papua New Guinea (Prud'homme Van reine et al., 1996; Belleza and Liao, 2007; Lewmanomont, 2008; Belton et al., 2014; Phang et al., 2016, Guiry, 2016). Indeed, Phang et al. (2016) recently reported that $C$. macrodisca only occurs in Singapore, Thailand and Vietnam around the South 
China Sea (SCS) region. None have reported on the occurence of $C$. macrodisca in Malaysian waters. The first occurence of C. macrodisca in the Sabah waters of Malaysia is an added information for the marine algae checklist around the SCS region. Malaysia is also located in the SCS region that encompasses a tropical location stretching from Singapore in the southwest to the Strait of Taiwan in the northeast across $22^{\circ}$ of latitute bounded by the coastlines of Malaysia, Thailand, Cambodia, Vietnam, China, the Philippines, Brunei and Indonesia.

The ecology of the recent $C$. macrodisca occurence area in Malaysian waters fit the nature of Caulerpa habitat. In general, Caulerpa sp. grow in marine and brackish water where the water is clear and slow current. The thallus is greenish and brownish depending on the quality of water and sediment (Tanduyan et al., 2013). Caulerpa sp. naturally inhabits a wide range of substrate consisting of rubbles to over 50 $\mathrm{m}$ deep, under surfaces of overhanging rocks, sand on reef flats and shallow, muddy lagoons and form beds and meadows. Most Caulerpa sp. occur in warm water and are not restricted only to the tropics. For instance, in Australia, numerous Caulerpa sp. occur along the warm-temperate southern coasts (Prud'homee Van Reine et al., 1996).

Caulerpa macrodisca was found to grow abundantly around the coastal area of Menumbok due to the suitability of the area as Caulerpa sp. habitat. The growth of Caulerpa sp. varies due to the differences on the environmental factors and the farming technique. The environmental and the physical factors that can influence the growth of Caulerpa sp. include water depth, water temperature, irradiance, salinity, sedimentation levels, wave action, $\mathrm{pH}$, oxygen content, seasonal variation, geographical difference and stocking density. The measured environmental parameters around the first occurrence habitat of C. macrodisca in Sabah waters fall in the range mentioned in the previous literature. Rabia (2016) stated that Caulerpa $\mathrm{sp}$. is sensitive to changes in salinity being stenohaline; salinities lower than $30 \mathrm{ppt}$ might result to poor growth and lower than $25 \mathrm{ppt}$ might cause mortality. The optimum temperatures and irradiances for growth of Caulerpa sp. vary depends on the species. The ranges could be from $15^{\circ} \mathrm{C}$ to $39^{\circ} \mathrm{C}$ and $30 \mu \mathrm{mol}$ photons $\mathrm{m}^{-2} \mathrm{~s}^{-1}$ to $60 \mu \mathrm{mol}$ photons $\mathrm{m}^{-2} \mathrm{~s}^{-1}$ (Guo et al., 2015). Irradiance would directly control the seaweed growth rate in nature through the activity on the pigment levels that could indirectly affect the photosynthetic ability of the seaweed (Soriano, 2012).

\section{Genetic and Morphology Analyses}

To date, numerous Caulerpa seaweed species that have been reported based on molecular identification (Fama et al., 2002; Cevik et al., 2007; Belton et al., 2014). The tufA gene analysis is a well established method to infer the phylogenetic relationships among taxa at different hierarchical rank of marine species (Fama et al., 2002). In addition, the tufA gene marker is recommended to be adopted as standard marker for the green marine macroalgae barcoding due to the strong amplification results produced by Saunders and Kucera (2010). The molecular analysis clearly clarified the Caulerpa X specimen that was obtained from Menumbok (Sabah) belonged to the genus Caulerpa as the specimen were grouped under the same clade in the phylogenetic tree.

Previous study reported that Caulerpa species was recognised with high misidentification rates $(>12 \%)$ as the identification was purely on morphological characteristics (Stam et al., 2006). This shows that morphological identification alone is unreliable compared to molecular approach. Identification of an organism by implementing both morphological and molecular methods are vital for validation 
of a species. In the current study, both approaches that were employed successfully identified a new record of $C$. macrodisca in Malaysia species which is Caulerpa X. The morphology of Caulerpa $\mathrm{X}$ specimens collected from the coastal area of Menumbok, Sabah reflected the usual morphology of $C$. macrodisca. This finding showed an agreement to genetic analysis where the morphology of Caulerpa $\mathrm{X}$ was similar with $C$. macrodisca that clustered together in the phylogenetic analysis.

Another interesting finding in this study was the obvious differences on the ramuli shape and size of $C$. macrodisca from this study compared to other studies by Belton et al. (2014) and Lewmanomont (2008). The maximum ramuli diameter of Caulerpa $\mathrm{X}$ was wider with approximately around $10 \mathrm{~mm}$ difference might be due to the different geographical and environmental factors adaptation. However, the exact difference factors were hard to confirm in this current study. In conclusion, the new record of $C$. macrodisca in the coastal waters of Menumbok, Sabah, Malaysia provided an updated information for the marine algae checklist around the SCS region.

\section{ACKNOWLEDGEMENTS}

This project was funded under the Universiti Malaysia Sabah UMS Great Grant (Grant No. GUG0034). We would like to acknowledge Mr. Ali Rahman, a local farmer in Menumbok, Sabah for the permission and the cooperation given during field sampling. Also special thanks to Dr. John M. Huisman and Professor Dr. Michael A. Borowitzka from Murdoch University for the aids in species identification of Caulerpa X.

\section{REFERENCES}

Belleza, D.F.C. \& Liao, L.M. (2007). Taxonomic inventory of the marine green algal genus Caulerpa (Chlorophyta, Bryopsidales) at the University of San Carlos (Cebu) herbarium. The Philippine Scientist. 44: 71-104.

Belton, G.S., Prud'homme Van Reine, W.F., Huisman, J.M., Draisma, S.G.A. \& Gurgel, C.F.D. (2014). Resolving phenotypic plasticity and species designation in the morphologically challenging Caulerpa racemosa-peltata Complex (Caulerpaceae, Chlorophyta). Journal of Phycology. 50 (1): 32-54.

Belton, G.S., Huisman, J.M. \& Gurgel, C.F.D. (2015). Caulerpaceae. In Huisman, J.M. [Eds.] Algae of Australia: marine benthic algae of north-western Australia. Green and brown algae. ABRS \& CSIRO Publishing, Canberra \& Melbourne, Australia. pp. 75-102.

Bridson, D. \& Forman, L. (1998). Herbaria. In Bridson, D. and Forman, L. [Eds.] The Herbarium Handbook. Royal Botanic Gardens, Australia. pp. 303317.

Cevik, C., Yokes, M.B., Cavas, L., Erkol, L.I., Derici, O.B. \& Verlaque, M. (2007). First report of Caulerpa taxifolia

(Bryopsidales, Chlorophyta) on the Levantine coast (Turkey, Eastern Mediterranean). Estuarine, Coastal and Shelf Science. 74: 549-556.

Cota-Sanchez, H., Remarchuk, K. \& Ubayasenaj. (2006). Ready-to-use DNA extracted with a CTAB method adapted for herbarium specimens and mucilaginous plant tissue. Plant Molecular Biology Reporter. 24: 161-167. 
Fama, P., Wysor, B., Kooistra, W.H.C.F. \& Zuccarello, G.C. (2002). Molecular phylogeny of the genus Caulerpa (Caulerpales, Chlorophyta) inferred from Chloroplast tufA Gene. Journal of Phycology. 38: 1040-1050.

Guiry, M.D. (2016). AlgaeBase. Available at: http://www.algaebase.org (last accessed 26 July 2016).

Guo, H., Yao, J., Sun, Z. \& Duan, D. (2014). Effect of temperature, irradiance on the growth of the green alga Caulerpa lentillifera (Bryopsidophyceae, Chlorophyta). Journal of Applied Phycology. 27: 879-885.

Larkin, M.A., Blackshields, G., Brown, N.P., Chenna, R., McGettigan, P.A., McWilliam, H., Valentin, F., Wallace, I.M., Wilm, A., Lopez, R., Thompson, J.D., Gibson, T.J. \& Higgins, D.G. (2007). Clustal W and clustal $\mathrm{X}$ version 2.0 . Bioinformatics. 23 (21): 2947-2948.

Lewmanomont, K. (2008). In Phang, S.M., Lewmanomont, K. \& Lim, P.E. [Eds.] Taxonomy of Southeast Asian seaweeds. Some Caulerpa and Caulerpella (Bryopsidales, Chlorophyta) from Thailand. Institute of Ocean and Earth Science (IOES), University of Malaya, Kuala Lumpur, Malaysia. pp. 27-32.

Movahhedin, N., Barar, J., Fathi, F.A., Barzegari, A. \& Nazemiyeh, $\mathrm{H}$. (2014). Phytochemistry and Biologic Activities of Caulerpa peltata Native to Oman Sea. Iranian Journal of Pharmaceutical Research. 13(2): 515-521.

Phang, S.M., Yeong, H.Y., Ganzon-Fortes, E.T., Lewmanomont, K., Prathep, A., Hau, L.N., Gerung, G.S. \& Tan, K.S. (2016). Marine algae of the South China Sea bordered by Indonesia, Malaysia, Philippines,
Singapore, Thailand and Vietnam. Raffles Bulletin Zoology. 34: 13-59.

Phang, S.M. (2007). Seaweed resources in Malaysia: Current status and future prospects. Aquatic Ecosystem Health Management. 9 (2): 185-202.

Price, I.R. (2011). A taxonomic revision of the marine green algal genera Caulerpa and Caulerpella ( Chlorophyta, Caulerpaceae) in northern (tropical and subtropical) Australia. Australian Systematic Botany. 24(3): 137-213.

Prud'homme Van Reine, W.F., Verheij, E. \& Coppejans, E. (1996). Species and ecads of Caulerpa (Ulvophyceae, Chlorophyta) in Malesia (SouthEast Asia): Taxonomy, Biogeography and Biodiversity. Netherland Journal of Aquatic Ecosystem. 30(2-3): 83-98.

Rabia, M.D.S. (2016). Cultivation of Caulerpa lentillifera using tray and sowing methods in brackishwater pond. Environmental Science. 4 (1): 23-29.

Saunders, G.W. \& Kucera, H. (2010). An evaluation of $r b c L$, tufA, UPA, LSU and ITS as DNA barcode markers for the marine green macroalgae. Cryptogamie, Algologie. 31(4): 487-528.

Soriano, E.M. (2012). Effect of depth on growth and pigment contents of the macroalgae Gracilaria bursapastoris. Brazillian Journal of Pharmacology. 22(4):730-735.

Stam, W.T., Olsen, J.L., Zaleski, S.F., Murray, S.N., Brown, K.R. \& Walters, L.J. (2006). A forensic and phylogenetic survey of Caulerpa species (Caulerpales, Chlorophyta) from the Florida Coast, local aquarium shops and E-commerce: Establishing a proactive baseline for 
early detection. Journal of Phycology. 42: 1113-1124.

Tanduyan, S.N., Gonzaga, R.B. \& Bensig, V.D. (2013). Off bottom culture of Caulerpa lentillifera in three different water levels in the marine waters of San Francisco, Cebu, Philippines. Journal of Coral Reef Studies. (Special Issue): 123-132. 